\title{
Exogenously Applied Trinexapac-ethyl Improves Photosynthetic Pigments, Water Relations, Osmoregulation and Antioxidants Defense Mechanism in Wheat under Salt Stress
}

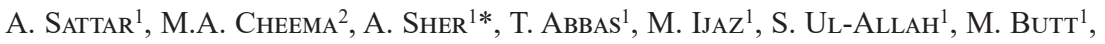 \\ A. QAYYUM ${ }^{3 *}$ and M. HUSSAIN ${ }^{4}$ \\ ${ }^{1}$ College of Agriculture, Bahauddin Zakariya University, Bahadur Sub-Campus Layyah, Pakistan \\ ${ }^{2}$ School of Science and the Environment, Grenfell Campus - Memorial University of Newfoundland, \\ Corner Brook, NL, Canada \\ ${ }^{3}$ Department of Agronomy, The University of Haripur, 22620 Pakistan \\ ${ }^{4}$ Department of Agronomy, Bahauddin Zakariya University, Multan, Pakistan \\ (Received 23 August 2018; Accepted 25 March 2019; \\ Communicated by I. Molnár)
}

The impact of trinexapac-ethyl (TE) on salinity subjected wheat plants was evaluated via pot based experiment. The treatments applied to wheat seedlings included (Ck) control (no $\mathrm{NaCl}$ nor TE spray), foliar spray of TE $\left(1.95 \mathrm{ml} \mathrm{L}^{-1}\right)$, only $\mathrm{NaCl}(50 \mathrm{mM})$ and $\mathrm{NaCl}+$ TE $\left(50 \mathrm{mM}+1.95 \mathrm{ml} \mathrm{L}^{-1}\right)$. Foliar application of TE was done seven days after imposition of salinity. Growth parameters (root length, shoot length, fresh weight, and dry weight) and photosynthetic pigments content (chlorophyll $a, b, a+b$ and $a / b$ ), water relation (water potential, osmotic potential, turgor potential and relative water contents) as well as catalase (CAT) activity exhibited marked reduction in comparison to control. In addition, an increment was noted in organic solutes content (proline, soluble protein and soluble sugar) and enzyme activity of superoxide dismutase (SOD), peroxidase (POD), and ascorbate peroxidase (APX) in stressed seedlings over control seedlings. The foliar applied TE mostly enhanced growth of salt stressed seedlings, accompanied by reinforcement in photosynthetic pigments, organic solutes, and enzyme activity (SOD, CAT, POD, and APX) in comparison to stressed seedlings. It is worthy to mention that, TE has potential to enhance salt tolerance of wheat seedlings. Thus, our findings suggest that seedling treated with TE is an effective strategy that can be used to enhance salt tolerance of wheat crop.

Keywords: antioxidants, osmo-protectants, salt tolerance, trinexapac-ethyl, water relations

\section{Introduction}

Increasing salt levels in cultivated area limit the crop productivity by imparting drastic effects on plants. Since last few decades, salt stressed conditions have been widely investigated, due to increase in its intensity and expansion of damage. The salt stress affects key physiological processes such as water relations, photosynthesis, osmotic adjustment

\footnotetext{
*Corresponding author; E-mails: ahmad.sher@bzu.edu.pk, aqayyum@uoh.edu.pk
} 
and oxidative metabolism (Farooq et al. 2015). It alters the plant's water relations by lowering soil water availability solution as a result of lowered osmotic potential (Farooq et al. 2015; Liu et al. 2014). The phenomenon of stomatal closure often observed in salttreated plants, protects tissue dehydration by limiting water losses (Fricke et al. 2004). It also induces the oxidative stress due to accumulation of reactive oxygen species (ROS), which modifies the cellular redox potential, favoringoxidized forms that can cause enzymes inactivation, leading to lipid peroxidation and damage DNA (Liuet al. 2014; Moldovan and Moldovan 2004). Changes in photosynthetic electron transport stimulate production of superoxide radicals which alter thylakoid membranes oxidative status and stomatal movement, leading to slow photosynthetic rate (Guerfel et al. 2009; GrijalvaContreras et al. 2012). The ROS accumulation is neutralized by antioxidant systems comprised of various scavengers, such as enzymes (superoxide dismutase (SOD), ascorbate peroxidase (APX), peroxidase (POD), and catalase (CAT) and non-enzymatic low molecular metabolites (proline, soluble sugar and carotenoids). Hence, the regulation of these plant antioxidant systems by exogenous supplementation of many substances (plant growth hormones, nutrients, osmolytes etc.) might arbitrate the plant tolerance to salt stress.

Trinexapac-ethyl (TE) being anti-gibberellins may possibly facilitate plant performance and development under unfavorable conditions but also increase stress tolerance in crop plants (Xu and Huang 2011). It was narrated that perennial rye grass (Lolium perenne) (Jiang and Fry 1998) and Kentucky bluegrass (Poapratensis L.) (Xu and Huang 2011) was able to survive under drought conditions through exogenous applied TE. In another study, it was reported that foliage applied TE significantly improved the performance of creeping bentgrass under high temperature and drought conditions (McCann and Huang 2007). Application of TE significantly enhanced the drought tolerance in plants by improving the water relations, photosynthetic attributes and osmotic adjustment (Bianet al. 2009). TE applied as foliar spray under saline conditions stimulated fresh and dry biomass, leaf pigments (chlorophyll and carotenoids) and lowered proline, sodium and chloride contents in paspalum turfgrass (Sakr 2009). Very first response was TE was observed as limiting mowing frequency of trufgrasses but now it has been established as plant growth mediator by stimulating water use efficiency, heat tolerance and shade tolerance (Wang et al. 2006; Steinke and Stier 2003; Zhang et al. 2003; Ervin et al. 2002). The TE provides a more compact and dense truf with smaller leaf blade that reduced soil evaporation. Reduction in evapo transpiration improves the water availability which may confirm the role of TE as growth enhancer under stressed conditions.

Although the impact of TE on various turfgrasses under drought stress is widely reported, yet there are no published data on its effects on wheat under salt stress. The current study evaluated the potential of TE on morpho-physiological and antioxidative responses of wheat against salt stress, and to indentify whether water relations, chlorophyll contents, enzymatic antioxidants activity, proline content, soluble protein and soluble sugar content (SSC) are implicated in salt tolerance of TE-treated wheat. 


\section{Materials and Methods}

A pot experiment was planned to determine the potential of TE in improving the salt tolerance in wheat (Triticum aestivum L.) seedlings at green house. Wheat variety Glaxay-2013 was used as an experimental material and its source was Ayub Agriculture Research Institute, Faisalabad, Pakistan. The 10 seeds were sown in each pot $[15.5 \mathrm{~cm} \times 60 \mathrm{~cm}($ diameter $\times$ height)] having $12 \mathrm{~kg}$ of well ground and fine soil. The physico-chemical properties of soil are shown in Table 1. In order to maintain the growth of seedling, basal dose of nitrogen $(\mathrm{N})$ at the rate of $100 \mathrm{mg} \mathrm{kg}^{-1}$ as urea, phosphorus $\left(\mathrm{P}_{2} \mathrm{O}_{5}\right) 90 \mathrm{mg} \mathrm{kg}^{-1}$ as diammonium phosphate and potassium $\left(\mathrm{K}_{2} \mathrm{O}\right) 60 \mathrm{mg} \mathrm{kg}^{-1}$ of soil as potassium sulphate was mixed well into soil. The 5 plants per pot were maintained. Fifteen days old seedlings were grown in each pot without salt treatments and were irrigated with deionized water. $\mathrm{NaCl}$ solution $(50 \mathrm{mM})$ was used to create artificial soil salinities which were started 15 days after seedlings emergence. Treatments included in the study were, viz. (Ck) control (no $\mathrm{NaCl}$ nor TE spray), TE (sprayed with $\left.1.95 \mathrm{ml} \mathrm{L}^{-1}\right)$, only $\mathrm{NaCl}(50 \mathrm{mM} \mathrm{NaCl}$ ) and $\mathrm{NaCl}+\mathrm{TE}\left(50 \mathrm{mM} \mathrm{NaCl}\right.$ with $\left.1.95 \mathrm{ml} \mathrm{L}^{-1} \mathrm{TE}\right)$. Foliar application of TE was done seven days with help of hand sprayer after imposition of salinity. The $10 \mathrm{ml}$ volume of solution was consumed for each pot. The experiment followed completely randomized design (CRD) with three replications.

Table 1. Physio-chemical properties of soil used in the experiment

\begin{tabular}{|l|c|}
\hline \multicolumn{1}{|c|}{ Soil analysis } & Value \\
\hline Mechanical analysis & 52 \\
\hline Sand (\%) & 22 \\
Silt (\%) & 27 \\
Clay (\%) & Sandy loam \\
Textural class \\
\hline Chemical analysis \\
\hline Soil pH \\
EC $\left(\mathrm{dSm}{ }^{-2}\right)$ & 8.5 \\
Cations exchangeable capacity $\left(\mathrm{dSm}^{-2}\right)$ & 2.32 \\
Organic matter $(\%)$ & 2.01 \\
Calcium carbonate $(\%)$ & 0.78 \\
Available Si $\left(\mathrm{mg} \mathrm{kg}^{-1}\right.$ soil) & 2.96 \\
Available Se $\left(\mathrm{mg} \mathrm{kg}^{-1}\right.$ soil) & 16 \\
\hline
\end{tabular}

\section{Growth characteristics}

Fifteen days past salinity treatments, wheat seedling was cut from the soil surface and the roots were cleaned to measure root and shoot lengths and fresh weights. For dry weights of root and shoot the samples were oven-dried at $75^{\circ} \mathrm{C}$ till a constant weight. Root shoot ratio was determined on dry weight basis. Root and shoot dry weights were pooled to estimate total dry biomass weight. 
For determination of relative water contents (RWC), fresh leaves $\left(\mathrm{W}_{\mathrm{f}}\right)(0.5 \mathrm{~g})$ were water rinsed till constant weight and weighed $\left(\mathrm{W}_{\mathrm{S}}\right)$. The water saturated leaves were then dried at $80{ }^{\circ} \mathrm{C}$ for $24 \mathrm{~h}$ todeterminedry weight $\left(\mathrm{W}_{\mathrm{d}}\right)$. The formula suggested by (Barrs and Weatherley 1962) was used to determine dry RWC as:

$$
\operatorname{RWC}(\%)=\left(\mathrm{W}_{\mathrm{f}}-\mathrm{W}_{\mathrm{d}}\right) /\left(\mathrm{W}_{\mathrm{S}}-\mathrm{W}_{\mathrm{d}}\right) \times 100
$$

Water potential $\left(\Psi_{\mathrm{w}}\right)$ of fresh leaf was determined by using pressure bomb (Santa Barbara, CA, USA). For osmotic potential $\left(\Psi_{\mathrm{s}}\right)$, same leaf was frozen, thawed, sap expressed, centrifuged $(5000 \times \mathrm{g})$ using an osmometer (Digital Osmometer, Wescor, Logan, UT, USA). The difference of $\Psi_{\mathrm{w}}$ and $\Psi_{\mathrm{s}}$ determined the Leaf pressure potential $\left(\Psi_{\mathrm{p}}\right)$.

For determination of leaf chlorophyll contents, grinding of $0.5 \mathrm{~g}$ leaf sample was done in $80 \%$ acetone to isolate chlorophyll. The absorbance of filtrate was determined through Spectrophotometer (Hitachi-U2001, Tokyo, Japan) at 663 and $645 \mathrm{~nm}$ as described by Arnon (1949).

For total soluble proteins, pre-chilled pastor mortar was used to ground fresh plant material (leaves) $(0.5 \mathrm{~g})$ with addition of $1 \mathrm{~mL}$ extraction buffer $(\mathrm{pH} 7.2)$. Before extraction of proteins, cocktail protease inhibitors $(1 \mu \mathrm{M})$ were added to the buffer. Phosphate buffer saline (PBS) was used, containing $10 \mathrm{mM} \mathrm{Na}_{2} \mathrm{HPO}_{4}, 2 \mathrm{mM} \mathrm{KH}_{2} \mathrm{PO}_{4}, 2.7 \mathrm{mM} \mathrm{KCl}$ and $1.37 \mathrm{mM} \mathrm{NaCl}$ dissolved in distilled water and volume was made up to $1 \mathrm{~L}$. $\mathrm{HCl}$ was used to adjust the pH 7.2 of PBS and then autoclaved (Sambrook and Russell 2001). The grounded leaf material was centrifuged at $12,000 \times \mathrm{g}$ for $5 \mathrm{~min}$. Supernatant was separated in centrifuge tube for the analysis of soluble proteins, following the Bradford assay (Bradford 1976). The absorbance for the sample supernatant was determined at $595 \mathrm{~nm}$ using spectrophotometer (UV 4000 UV-VIS spectrophotometer). Concentration (mg $\mathrm{mL}^{-1}$ ) of total soluble or heat stable fractions of proteins was calculated using a standard curve prepared from bovine serum albumin (BSA). For enzymatic antioxidants determination, $5 \mathrm{ml}$ of $50 \mathrm{mM}$ phosphate buffer ( $\mathrm{pH}$ 7.8) was used for extraction of fresh leaf sampleand centrifuged at $15,000 \times \mathrm{g}$ for $20 \mathrm{~min}$, the supernatant was used in further assay for superoxide dismutase (SOD) activity (Giannopolitis and Ries 1977), Catalase (CAT) activity (Chance and Maehly 1955) by recording absorbance at 560 and $240 \mathrm{~nm}$, respectively. The SOD activity was determined by monitoring inhibition of the photochemical reduction of nitroblue tetrazolium (NBT) at $560 \mathrm{~nm}$ and expressed as SOD IU min ${ }^{-1} \mathrm{mg}^{-1}$ protein. The reaction mixture included $50 \mu \mathrm{L}$ enzyme extract and adding $1 \mathrm{ml}$ NBT $(50 \mu \mathrm{M}), 500 \mu \mathrm{L}$ methionine $(13 \mathrm{mM}), 1 \mathrm{~mL}$ riboflavin $(1.3 \mu \mathrm{M}), 950 \mu \mathrm{L}(50 \mathrm{mM})$ phosphate buffer and $500 \mu \mathrm{L}$ EDTA $(75 \mathrm{mM})$. The reaction was started by keeping reaction solution under $30 \mathrm{~W}$ fluorescent lamp illuminations and turning the fluorescent lamp on. Reaction stopped when the lamp turned off 5 min later. The NBT photo reduction produced blue formazane which was used to measure the increase in absorbance at $560 \mathrm{~nm}$. The same reaction mixtures without enzyme extract in dark were used as a blank. The CAT activity was assayed by the decomposition of $\mathrm{H}_{2} \mathrm{O}_{2}$ and change in absorbance due to $\mathrm{H}_{2} \mathrm{O}_{2}$ was observed after every $30 \mathrm{~s}$ for $5 \mathrm{~min}$ at $240 \mathrm{~nm}$ using a UV-visible spectrophotometer. Reaction mixture for CAT contained $900 \mu \mathrm{L} \mathrm{H}_{2} \mathrm{O}_{2}(5.9 \mathrm{mM})$ and $2 \mathrm{~mL}$ phosphate 
buffer $(50 \mathrm{mM})$. Reaction was started by adding $100 \mu \mathrm{L}$ enzyme extract to the reaction mixture. The CAT activity was expressed as $\mu \mathrm{mol}$ of $\mathrm{H}_{2} \mathrm{O}_{2} \mathrm{~min}^{-1} \mathrm{mg}$ protein ${ }^{-1}$ (Chance and Maehly 1955). The POD activity was determined according to Kara and Mishra (1976). The reaction mixture consisted of $2.5 \mathrm{ml}$ Tris- $\mathrm{HCl}$ buffer $(0.1 \mathrm{M}), 2.5 \mathrm{ml} \mathrm{H}_{2} \mathrm{O}_{2}$ $(5 \mathrm{mM}), 2.5 \mathrm{ml}$ pyrogallol $(10 \mathrm{mM})$ and $50 \mu \mathrm{l}$ enzyme extract. The $\mathrm{H}_{2} \mathrm{O}_{2}$ dependent oxidation of pyrogallol was followed by a decrease in the absorbance at $425 \mathrm{~nm}$. Proline was determined as described by Bates et al. (1973). Fresh leaf tissues $(0.5 \mathrm{~g})$ from each treatment were homogenized in $10 \mathrm{~mL}$ of $3 \% \mathrm{w} / \mathrm{v}$ sulphosalicylic acid, and the homogenate was filtrated. The resulting solution was treated with $2.5 \%$ ninhidrine solution and glacial acetic acid. In test tubes, the reaction mixtures were kept in a water bath at $100{ }^{\circ} \mathrm{C}$ for 60 min to develop the color. Soon after removal from the water bath, the test tubes were cooled in ice bath and toluene was added to separate chromophores. Optical density was read at $520 \mathrm{~nm}$ using UV-VIS spectrophotometer. The concentrations of soluble sugar were determined in this extract as described by Giannakoula et al. (2008).

Fisher's Analysis of Variance technique was used to analyze collected data. Least Significant Difference (LSD) test at 5\% probability level was applied to compare the treatment's means (Steel et al. 1997).

\section{Results}

Salt stress implemented adverse effects on wheat seedlings as evident from the reduced growth attributes. The sole application of TE contributed at par response of growth attributes (shoot dry weight, root dry weight and total seedling biomass) with control (Table 2). However, the TE application response in terms of shoot and root length followed control plants. Application of TE on salt stressed wheat seedlings improved shoot dry weight, root dry weight, shoot length, root length and total seedling biomass as compared to salt stressed plants.

Salt stress resulted in reduction of water potential $\left(\Psi_{\mathrm{w}}\right)$, osmotic potential $\left(\Psi_{\mathrm{s}}\right)$ and relative water contents of the wheat seedlings, when compared with control. Application of TE without salt stress cause less reduction in $\Psi_{\mathrm{w}}$ and $\Psi_{\mathrm{s}}$ as compared to salt stressed seedlings. Supplementation of TE under salt stress also contributed in less reduction of $\Psi_{\mathrm{w}}$ and $\Psi_{\mathrm{s}}$ in comparison to salt stressed seedlings (Table 3). Salt application improved turgor potential of wheat seedlings, which was reduced in case of TE application, however when TE was applied to salt stressed seedlings, turgor potential was found to be at par with salt stressed seedlings. TE application under salt stress, improved relative water contents of the wheat seedlings.

Photosynthetic pigments vary significantly in response to salt stress and TE application. Salt stress reduced the chlorophyll $a, b$ and $a+b$. The solo application of TE showed at par response with control (Table 4). The TE application under salt stress improved chlorophyll $a, b$ and $a+b$ in comparison to saline treatment. The response of chlorophyll $a / b$ remained non-significant under various treatments applied.

Saline conditions increased the enzymatic activity of the wheat seedlings. Superoxide dismutase was found to be maximum when saline conditions were supplemented with TE 


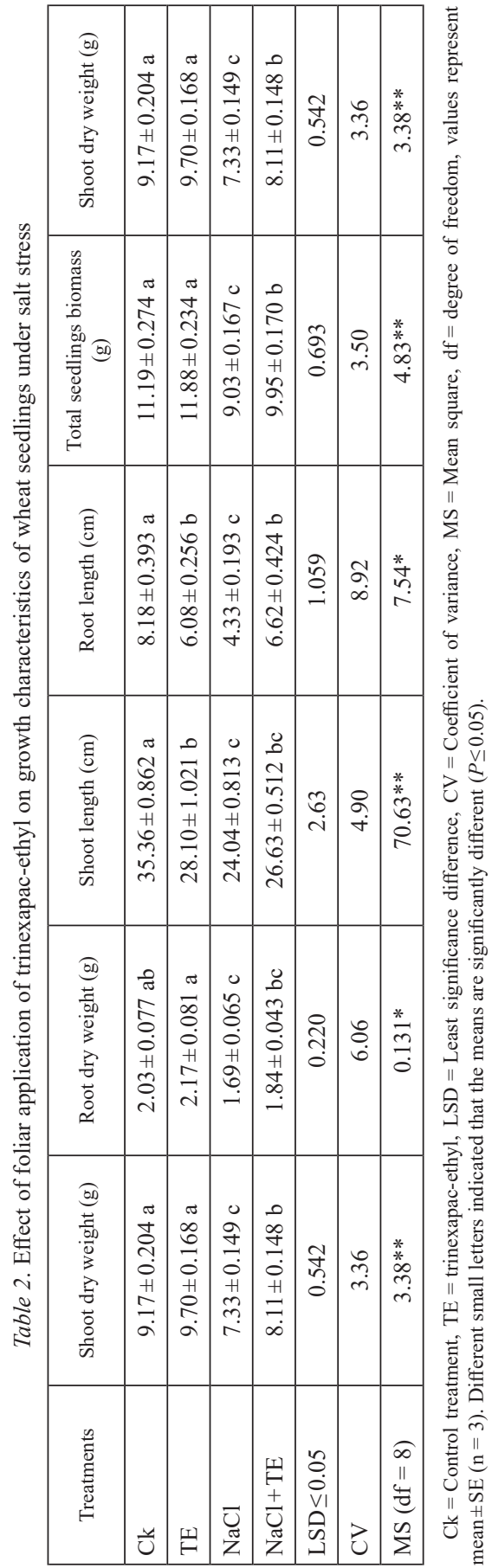

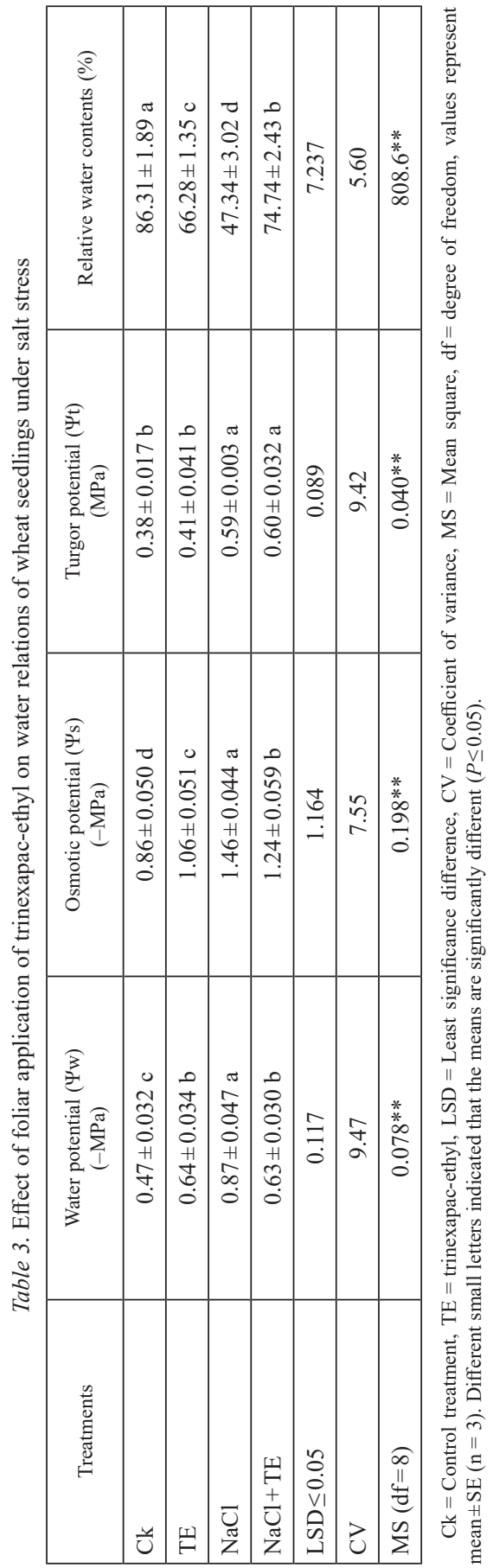

Cereal Research Communications 47, 2019 

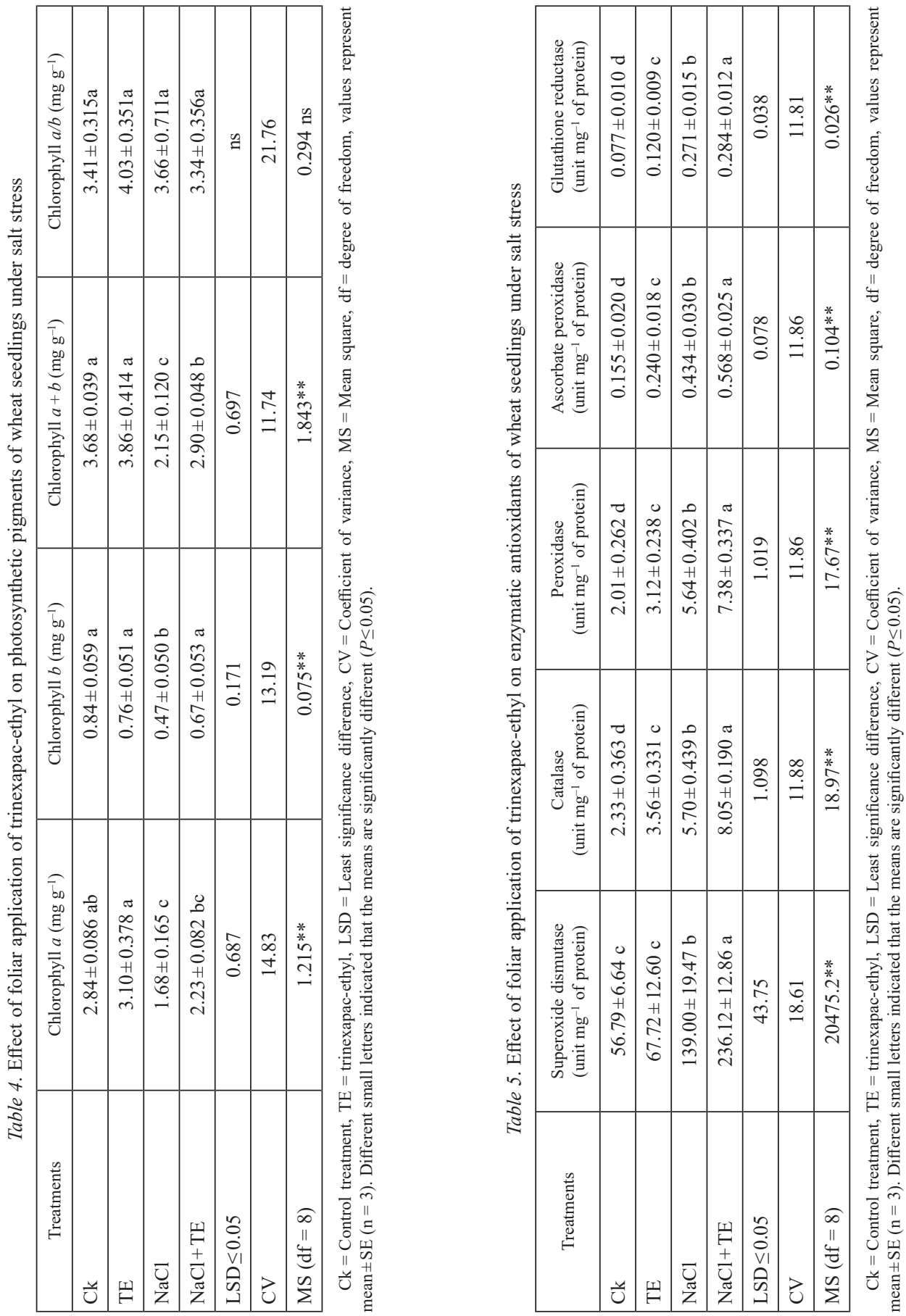
with a percentage increase of $70 \%$, when compared with saline conditions and $316 \%$, when compared with control (without salt treatment). The percentage increase of catalase activity of wheat seedlings with sole application of TE was observed to be $53 \%$, with saline treatment only as $145 \%$ and with TE application with salt stress as $245 \%$, when compared with control (Table 5). However, the percentage increase of $41 \%$ was observed in catalase activity in response to $\mathrm{NaCl}+\mathrm{TE}$, when compared with saline conditions. $\mathrm{TE}$ application with and without saline conditions resulted in improved peroxidase activity of wheat seedlings with percentage increase of $55 \%$ and $67 \%$, when compared with control. The percentage increase of 31 was observed when $\mathrm{NaCl}+\mathrm{TE}$ was compared with saline conditions. APX activity was observed to increase by a percentage of 55 and 266, when TE was applied alone and under saline conditions, respectively. In comparison to saline conditions, 31\% increase in APX activity was observed in response to $\mathrm{NaCl}+\mathrm{TE}$ treatment. Increment in glutathione reductase (GR) activity was also noted to be $56 \%$ and $269 \%$ in TE application and $\mathrm{NaCl}+\mathrm{TE}$ application, respectively (Table 5). The percentage increase of $6 \%$ was observed in treatment $\mathrm{NaCl}+\mathrm{TE}$, when compared with saline conditions.

Proline contents were incremented by $27 \%, 59 \%$ and $115 \%$ with application of TE, $\mathrm{NaCl}$ and $\mathrm{NaCl}+\mathrm{TE}$, respectively, when compared with control. The increment was $35 \%$, when application of $\mathrm{NaCl}+\mathrm{TE}$ was compared with saline (Table 6). Soluble protein contents were found to be reduced under saline conditions but increased with application of TE alone and TE under saline conditions. This increase was 32\% and $111 \%$, respectively as compared to control conditions. Under saline conditions, the increase of soluble proteins was observed to be $148.14 \%$, with application of TE. Saline conditions improved soluble sugars by $114 \%$, TE alone and under saline conditions enhanced soluble sugars by $53 \%$ and $219 \%$, in comparison to control (Table 6). The increment was $49 \%$, when TE application under saline conditions was compared with saline treatment.

Table 6. Effect of foliar application of trinexapac-ethyl on osmo-protectants of wheat seedlings under salt stress

\begin{tabular}{|l|c|c|c|}
\hline \multicolumn{1}{|c|}{ Treatments } & Proline $\left(\mu \mathrm{mol} \mathrm{g} \mathrm{g}^{-1} \mathrm{FW}\right)$ & Soluble protein $\left(\mathrm{mg} \mathrm{g}^{-1} \mathrm{FW}\right)$ & Soluble sugar $\left(\mathrm{mg} \mathrm{g}^{-1} \mathrm{FW}\right)$ \\
\hline $\mathrm{Ck}$ & $5.47 \pm 0.38 \mathrm{c}$ & $1.59 \pm 0.34 \mathrm{~b}$ & $1.91 \pm 0.49 \mathrm{c}$ \\
\hline $\mathrm{TE}$ & $6.93 \pm 0.49 \mathrm{c}$ & $2.10 \pm 0.16 \mathrm{~b}$ & $2.93 \pm 0.35 \mathrm{bc}$ \\
\hline $\mathrm{NaCl}$ & $8.71 \pm 0.44 \mathrm{~b}$ & $1.35 \pm 0.28 \mathrm{~b}$ & $4.08 \pm 0.18 \mathrm{~b}$ \\
\hline $\mathrm{NaCl}+\mathrm{TE}$ & $11.78 \pm 0.67 \mathrm{a}$ & $3.35 \pm 0.15 \mathrm{a}$ & $6.09 \pm 0.40 \mathrm{a}$ \\
\hline $\mathrm{LSD} \leq 0.05$ & 1.64 & 0.80 & 1.20 \\
\hline $\mathrm{CV}$ & 10.61 & 20.46 & 17.07 \\
\hline $\mathrm{MS}(\mathrm{df}=8)$ & $22.14^{* *}$ & $2.36^{*}$ & $9.60^{* *}$ \\
\hline
\end{tabular}

$\mathrm{Ck}=$ Control treatment, $\mathrm{TE}=$ trinexapac-ethyl, $\mathrm{LSD}=$ Least significance difference, $\mathrm{CV}=$ Coefficient of variance, $\mathrm{MS}=$ Mean square, $\mathrm{df}=$ degree of freedom, $\mathrm{FW}=$ Fresh weight, values represent mean $\pm \mathrm{SE}(\mathrm{n}=3)$. Different small letters indicated that the means are significantly different $(P \leq 0.05)$. 


\section{Discussion}

Plant growth regulators have the ability to alter the plant physiological activities. Trinexapac-ethyl (TE) is typically a growth inhibitor which counteracts the conversion of inactive gibberellic acid to its metabolically active form (Xu and Huang 2011; Matysiak 2006). The TE applied under salt stressed conditions in wheat stimulated the growth parameters. The physiological modulation reduces the plant shoot and root length under normal conditions, as depicted by the results of current study. The response of TE application under salt stress however modified the plant behavior, which resulted in improved growth attributes (Sakr 2009). The current investigation also led to improved chlorophyll contents and its components as well as water relations of TE treated salt stressed wheat seedlings. The improved growth parameters can be attributed to improved water relations and photosynthetic activity of the salt stressed plants, supplemented with TE (Jiang and Fry 1998). The TE application did not increase the shoot length considerably but maintained the total chlorophyll contents and its components. The dark green appearance of these TE treated wheat seedlings was due to increased chlorophyll contents and mesophyll cell density, as supported by Ervin and Koski (2001); Heckman et al. (2005) and McCullough et al. (2006). Slow degradation of chlorophyll contents under salt stress enhances the photosynthetic efficiency of the plants thus increase their stress tolerance (Arghavani et al. 2012).

Salt stress negatively impacted the water relations of wheat seedlings. The TE application under salt stress improved these parameters, by maintaining higher relative water contents and turgor potential. Maintenance of high RWC is an indication of improved survival rate of plant under salt stressed conditions. Decreased water potential and solute potential as a result of TE application under stress can be a reason of improved relative cellular hydration level (Etemadi et al. 2015). Reduced solute potential of TE applied salt stressed wheat seedlings can be attributed to slow growth rate of plants, which is accomplished by less utilization of assimilates (Munns 1988; Fan et al. 2009). It can also be related to stress tolerance induction by TE application through slow growth rate and improved osmotic adjustment (Stier and Rogers 2001). Osmotic adjustment is a physiological phenomenon associated with accumulation of solutes and inorganic ions which leads to improved survival rate of plants under stress conditions (Elansarya and Salem 2015; Koch et al. 2017). Proline contents, soluble protein and soluble sugars can be regarded as osmolites used for osmotic adjustment. Such solute accumulation reduced the solute potential of the plants. The stressed conditions increased the proline and soluble sugar contents, which was more improved by TE application. The increased soluble sugar contents of TE treated plants enables the more availability of free sugars for osmotic adjustment (Bian et al. 2009).

Production of ROS is a prominent phenomenon of abiotic stresses including salt stress. The ROS have the ability to disrupt cellular membranes, damage DNA and modify the cell metabolism (Foyer et al. 1994). Plants have inherent ability to scavenge ROS through antioxidants including enzymes and organic molecules. The enzymes convert the highly active oxygen species into harmless water and oxygen (Fu and Huang 2001). The studied 
enzymatic activity of SOD, POD, CAT, APX and GR increased following TE application under salt stress. The phenomenon of increased antioxidant activity due to TE application is not fully understood but it can be linked to lower MDA contents (Chen et al. 2009). Less MDA contents refer to less oxidative damage to cellular membranes. The TE may serve to improve the cellular thermo-stablility (Heckman et al. 2002) which led to less susceptibility of oxidative stress damage. The prominent effects of TE under salt stress are depicted by growth promotion, enhanced chlorophyll contents, improved water relations and antioxidant enzyme activity coupled with accumulation of osmolites furnishes its use to induce salt stress (Baldwin et al. 2006).

\section{Conclusion}

From the results it is concluded that TE application decrease damages to wheat seedlings under salt stress probably via improving growth attributes, water relations, chlorophyll contents, antioxidant activity and osmo-protectants content. As salt stress increased, enzyme activity decreased, but ROS injury to the cells increased. Wheat seedlings were found to have a higher activities of SOD, CAT, POD and APX activities, more water relations attributes, chlorophyll contents, and osmo-protectants content during the salt-stress period when treated with TE. Thus, our findings suggest that a seedling treated with TE is an effective strategy that can be used to enhance salt tolerance of wheat crop.

\section{References}

Arghavani, M., Kafi, M., Babalar, M., Naderi, R., Hoque, M.A., Murata, Y. 2012. Improvement of salt tolerance in Kentucky bluegrass by trinexapac-ethyl. Hortic. Sci. 47:1163-1170.

Arnon, D.T. 1949. Copper enzyme in isolated chloroplasts polyphenoloxidase in Beta vulgaris. Plant Physiol. 24:1-15.

Baldwin, C.M., Liu, L.B., McCarty, W.L., Bauerle, M., Toler, J.E. 2006. Effects of trinexapac-ethyl on the salinity tolerance of two bermudagrass cultivars. Hortic. Sci. 41:808-814.

Barrs, H.D., Weatherley, P.E. 1962. A re-examination of the relative turgidity technique for estimating water deficits in leaves. Aus. J. Biol. Sci. 15:413-428.

Bates, L.S., Waldren, R.P., Teare, I.D. 1973. Rapid determination of free proline for water-stress studies. Plant Soil 39:205-207.

Bian, X., Merewitz, E., Huang, B. 2009. Effects of trinexapac-ethyl on drought responses in creeping bentgrass associated with water use and osmotic adjustment. J. Am. Soc. Hortic. Sci. 134:505-510.

Bradford, M. 1976. A rapid and sensitive method for the quantitation of microgram quantities of protein utilizing the principle of protein-dye binding. Ann. Biochem. Exp. Med. 72:248-254.

Chance, M., Maehly, A.C. 1955. Assay of catalases and peroxidases. Methods Enzymol. 12:764-772.

Chen, C., Lu, S., Chen, Y., Wang, Z., Niu, Y., Guo, Z. 2009. A gamma-ray induced dwarf mutant from seeded bermudagrass and its physiological responses to drought stress. Hortic. Sci. 134:22-30.

Elansarya, H.O., Salem, M.Z.M. 2015. Morphological and physiological responses and drought resistance enhancement of ornamental shrubs by trinexapac-ethyl application. Hortic. Sci. 18:1-11.

Ervin, E.H., Koski, A.J. 2001. Kentucky bluegrass growth responses to trinexapac-ethyl, traffic, and nitrogen. Crop Sci. 41:1871-1877.

Ervin, E.H., Ok, C.H., Fresenburg, B.S., Dunn, J.H. 2002. Trinexapac-ethyl restricts shoot growth and prolongs stand density of 'Meyer' zoysiagrass fairway under shade. Hortic. Sci. 37:502-505. 
Etemadi, N., Mohammadi, M.H.S., Nikbakht, A., Sabzalian, M.R., Pessarakli, M. 2015. Influence of trinexapac-ethyl in improving drought resistance of wheatgrass and tall fescue. Acta Physiol. Plant. 37:53-59.

Fan, G., Bian, X., Li, H., Menh, Z., Liu, S. 2009. Growth responses of Kentucky bluegrass (Poapratensis L.) to trinexapac-ethyl applied in spring and autumn. Front. Agric. China 3:186-189.

Farooq, M., Hussain, M., Wakeel, A., Siddique, K.H.M. 2015. Salt stress in maize: effects, resistance mechanisms, and management, A review. Agron. Sustain. Dev. 35:461-481.

Foyer, C.H., Lelandais, M., Kunert, K.J. 1994. Photo-oxidative stress in plants. Physiol. Plant. 92:696-717.

Fricke, W., Akhiyarova, G., Veselov, D., Kudoyarova, G. 2004. Rapid and tissue-specific changes in ABA and in growth rate in response to salinity in barley leaves. J. Exp. Bot. 55:1115-1123.

$\mathrm{Fu}$, J., Huang, B. 2001. Involvement of antioxidants and lipid peroxidation in the adaptation of two cool-season grasses to localized drought stress. Environ. Exp. Bot. 45:105-114.

Giannakoula, A., Moustakas, M., Mylona, P., Papadakis, I., Yupsanis, T. 2008. Aluminium tolerance in maize is correlated with increased levels of mineral nutrients, carbohydrates and proline and decreased levels of lipid peroxidation and Al accumulation. J. Plant Physiol. 165:385-396

Giannopolitis, C.N., Ries, S.K. 1977. Superoxide dismutase. I. Occurrence in higher plants. Plant Physiol. 59:309-314.

Grijalva-Contreras, R.L., Macías-Duarte, R., Martínez-Díaz, G., Robles-Contreras, F., Nuñez-Ramírez, F. 2012. Effects of trinexapac-ethyl on different wheat varieties under desert conditions of Mexico. Agric. Sci. 3:658-662.

Guerfel, M., Baccouri, O., Boujnah, D., Chaibi, W., Zarrouk, M. 2009. Impacts of water stress on gas exchange, water relations, chlorophyll content and leaf structure in the two main Tunisian olive (Oleaeuropaea L.) cultivars. Hortic. Sci. 119:257-263.

Heckman, N.L., Horst, G.L., Gaussoin, R.E., Tavener, B.T. 2002. Trinexapac-ethyl influence on cell membrane thermostability of Kentucky bluegrass leaf tissue. Hortic. Sci. (Amsterdam) 92:183-186.

Heckman, N.L., Gaussoin, R.E., Horst, G.L., Elowsky, C.G. 2005. Growth regulator effects on cellular characteristics of two turfgrass species. Int. Turfgrass Soc. Res. J. 10:857-861.

Jiang, H., Fry, J. 1998. Drought responses of perennial ryegrass treated with plant growth regulators. Hortic. Sci. 33:270-273.

Kara, M., Mishra, D. 1976. Catalase, peroxidase, poly phenoloxidase activities during since leaf senescence. Plant Physiol. 54:315-319.

Koch, F., Zimmer, G., Monteiro, M.A., Martins, M.C., Delias, D.S., Troyjack, C., Szareski, V.J., Borges, E.G., Pedó, T., do Amarante, L., Villela, F.A., Aumonde, T.Z. 2017. Chemical composition and physiological quality of wheat seeds with the application of trinexapac-ethyl, a plant growth regulator. Aust. J. Crop Sci.11:1527-1533.

Liu, S.Y., Dong, L., Xu, Y., Kong, J. 2014. Effects of foliar applications of nitric oxide and salicylic acid on salt-induced changes in photosynthesis and antioxidative metabolism of cotton seedlings. Plant Growth Regul. 73:67-78.

Matysiak, K. 2006. Influence of trinexapac-ethyl on growth and development of winter wheat. J. Protect. Res. 46:133-143.

McCann, S.E., Huang, B. 2007. Effects of trinexapac-ethyl foliar application on creeping bentgrass responses to combined drought and heat stress. Crop Sci. 47:2121-2128.

McCullough, P.E., Liu, H., McCarty, L.B., Whitwell, T., Toler, J.E. 2006. Growth and nutrient partitioning of 'TifEagle' bermudagrass as influenced by nitrogen and trinexapac-ethyl. Hortic. Sci. 41:453-458.

Moldovan, L., Moldovan, N.I. 2004. Oxygen free radicals and redox biology of organelles, Histochem. Cell Biol. 122:395-412.

Munns, R. 1988. Why measure osmotic adjustment? Aust. J. Plant Physiol. 115:717-726.

Sakr, W.R.A. 2009. Response of paspalumturfgrass grown in sandy soil to trinexapac-ethyl and irrigation water salinity. Hort. Sci. Ornamen Plants 1:15-26.

Sambrook, J., Russell, D.W. 2001. Molecular Cloning: A Laboratory Manual 3rd Edition. Chapter 18: Protein interaction technologies, protocol \#3: Detection of protein-protein interactions using the GST fusion protein pull-down technique. Cold Spring Harbor Laboratory Press. 
Steel, R.G.D., Torrie, J.H., Dickey, D.A. 1997. Principles and procedures of statistics:a biometric approach, $3^{\text {rd }}$ Ed. McGraw Hill Book Co. Inc. New York, USA.

Steinke, K., Stier, J.C. 2003. Nitrogen selection and growth regulator applications for improving shade turf performance. Crop Sci. 43:1399-1406.

Stier, J.C., Rogers, J.N. 2001. Trinexapac-ethyl and iron effects on supina and Kentucky bluegrasses under low irradiance. Crop Sci. 41:457-465.

Wang, Z., Sun, J., Li, J., Zhu, Y. 2006. Heat resistance enhanced by trinexapac-ethyl and benzyladenine combination in creeping bentgrass. Hort. Sci. 41:1711-1714.

Xu, C., Huang, B. 2011. Proteins and metabolites regulated by trinexapac-ethyl in relation to drought tolerance in Kentucky bluegrass. J. Plant Growth Regul. 31:25-37.

Zhang, X., Ervin, E.H., Schmidt, R.E. 2003. Plant growth regulator can enhanced the recovery of Kentucky bluegrass sod from heat injury. Crop Sci. 43:952-958. 